\title{
WZMOCNIENIE REGULACJI NA HURTOWYCH RYNKACH ENERGII ELEKTRYCZNEJ W ŚWIETLE ROZPORZĄDZENIA UE NR 1227/2011 (REMIT)
}

\section{Uwagi ogólne}

Kryzys finansowy wykazał niedoskonałości istniejące na hurtowych rynkach energii. Uwypuklił bowiem, iż procesy mające na nich miejsce powiązane są w znaczący sposób z globalnymi zdarzeniami zachodzącymi na rynkach finansowych, a podmioty aktywnie działające na rynkach finansowych niejednokrotnie bywają również kluczowymi graczami na hurtowych rynkach energii ${ }^{1}$.

Należy jednocześnie pamiętać, iż hurtowy rynek energii jest podstawą dla decyzji inwestycyjnych w elektroenergetyce. Konieczne jest więc istnienie stosownych mechanizmów stanowiących gwarancję jego właściwego funkcjonowania - wszelkie zakłócenia prawidłowości jego funkcjonowania mogą bowiem prowadzić do niewłaściwej alokacji inwestycji, wzrostu zmienności cen energii elektrycznej, a w efekcie do niezasadnie wysokich jej cen dla odbiorcy końcowego ${ }^{2}$. W odpowiedzi na niniejsze zagrożenia za zasadne uznano skorzystanie $\mathrm{z}$ narzędzi mających zapewnić istnienie silnych i stabilnych ram regulacyjnych

* Mgr Mateusz Radziński - Autor przygotowuje rozprawę doktorską z zakresu prawa energetycznego na Wydziale Prawa i Administracji Uniwersytetu Łódzkiego w Katedrze Prawa Gospodarczego Publicznego.

1 D. Michalski, Wpływ nowych regulacji KE na funkcjonowanie przedsiębiorstw elektroenergetycznych (cz. I), http://www.korporacyjnie.pl/wplyw-nowych-regulacji-komisji-europejskiej-na -funkcjonowanie-przedsiebiorstw-elektroenergetycznych-czesc-i/ (data pobrania: 21.10.2015 r.).

Ibidem. 
gwarantujących przejrzystość i integralność hurtowych rynków energii. U podstaw wprowadzenia tych mechanizmów legło więc przekonanie o konieczności poddania hurtowych rynków energii zasadom zbliżonym do regulacji funkcjonujących na rynkach finansowych.

Jednym z takich narzędzi jest rozporządzenie Parlamentu Europejskiego i Rady (UE) Nr 1227/2011 z 25.10.2011 r. w sprawie integralności i przejrzystości hurtowego rynku energii (dalej jako: REMIT, ang. Rgulation on wholesale Energy Market Integrity and Transparency), które ustanawia przepisy określające obowiązki informacyjne i zakazy stosowania praktyk stanowiących nadużycia (manipulacje) na hurtowym rynku energii (zarówno w stosunku do energii elektrycznej, jak i paliw gazowych), analogiczne do przepisów przyjętych wcześniej w stosunku do rynków finansowych ${ }^{3}$ m.in. w oparciu o dyrektywę MAD (ang. Market Abuse Directive) ${ }^{4}$.

W kontekście liberalizacji rynku energii elektrycznej w UE, rozporządzenie REMIT może być postrzegane jako instrument mający na celu uzupełnienie polityki na rzecz zaistnienia konkurencji w niniejszym sektorze w celu stworzenia prawidłowo funkcjonującego rynku wewnętrznego ${ }^{5}$. Proces liberalizacji rynków energetycznych pokazał bowiem, iż działające na nim podmioty nie poddają się samoregulacji rynkowej, a tym samym nie zapewniają automatycznie przejrzystości i uczciwości podejmowanych działań, dlatego też uzasadnione jest wprowadzenie właściwych instrumentów prawnych pozwalających nakładać na nie określone obowiązki.

Od samego początku podstawowym celem działań podejmowanym przez ustawodawcę unijnego w sektorze energetycznym było stworzenie mechanizmu konkurencji mającego zapewnić niedyskryminacyjny dostęp do tego rynku wszystkim zainteresowanym podmiotom oraz eliminować antykonkurencyjne zachowania podmiotów posiadających znaczącą pozycję rynkową. REMIT stanowi ważny element tej polityki wprowadzając m.in. przepisy nakazujące podawanie

3 T. Brzeziński, A. Mathews, Obowiq̨zki informacyjne wynikające z REMIT dla uczestników rynków energii elektrycznej i paliw gazowych, „Nowa Energia” 2014, nr 4, s. 23, http://wawrzynowicz. eu/category/publikacja/ (data pobrania: 17.2.2015 r.).

4 Dyrektywa 2003/6/WE Parlamentu Europejskiego i Rady z 28.1.2003 r. w sprawie wykorzystywania poufnych informacji i manipulacji na rynku (nadużyć na rynku), Dz.Urz. UE $2003 \mathrm{Nr}$ L 96. Przedmiotowa dyrektywa uchylona została na mocy Rozporządzenia Parlamentu Europejskiego i Rady nr 596/2014 z 16.4.2014 r. w sprawie nadużyć na rynku, Dz.Urz. 2014 UE Nr L 173/1. Wraz z niniejszym rozporządzeniem przyjęto również Dyrektywę Parlamentu Europejskiego i Rady nr 2014/57/UE z 16.4.2014 r. w sprawie sankcji karnych za nadużycia na rynku, Dz.Urz. UE 2014 Nr L 173/179).

5 E. Michetti, European Energy Markets Transparency Report - 2012 edition, Florence School of Regulation, s. 3, http://fsr.eui.eu/Documents/ResearchReport/Energy/2012/RR2012ETA.pdf (data pobrania: 20.1.2015 r.). 
określonych informacji do wiadomości publicznej, jak również eliminujące możliwości wykorzystywania pewnych informacji ze szkodą dla konkurencji ${ }^{6}$.

Większa przejrzystość rynku zapewnia, iż dostępnych jest więcej informacji, które w świetle jego dobrego funkcjonowania mogą pozwolić podmiotom na nim działającym, na właściwą ocenę sytuacji rynkowej przed podjęciem określonych działań. Pozwala to na tworzenie równych szans dla wszystkich uczestników rynku, jak również zmniejsza zakres praktyk antykonkurencyjnych. REMIT wprowadza bowiem - dokonując pewnego uogólnienia - instrumenty wskazujące jaka informacja, kiedy, komu i na jakich warunkach może zostać ujawniona. Z kolei większa integralność oznacza, iż dostępne informacje wykorzystywane są w uczciwy sposób ${ }^{8}$. W tym zakresie REMIT odgrywa istotną rolę wprowadzając z jednej strony, mechanizmy mające zapobiegać nadużyciom na rynku, które powinny być sankcjonowane, z drugiej strony, ustalając obowiązki monitorowania i nadzoru mające wykrywać i zapobiegać takim nadużyciom. Jak zauważono w pkt. 4 preambuły REMIT hurtowe rynki energii w całej Unii sq̨ ze sobq coraz ściślej powiqzane. Nadużycia na rynku w jednym państwie członkowskim często maja wpływ nie tylko na kształtowanie się cen hurtowych energii elektrycznej i gazu ziemnego poza granicami tego państwa, ale również na ceny detaliczne dla konsumentów i mikroprzedsiębiorstw. Dlatego też troski o zapewnienie integralności rynków nie można pozostawić wyłącznie poszczególnym państwom członkowskim. Ścisłe transgraniczne monitorowanie rynku ma kluczowe znaczenie dla osiągnięcia w pełni funkcjonującego, wzajemnie połączonego i zintegrowanego wewnętrznego rynku energii.

Rozporządzenie REMIT oparte zostało na trzech zasadniczych filarach: (1) zakazie wykorzystywania informacji wewnętrznych, (2) zakazie manipulacji na rynku oraz (3) monitorowaniu rynku przez Agencję ds. Współpracy Organów Regulacji Energetyki (dalej jako: ACER) przy ścisłej współpracy z krajowymi organami regulacyjnymi ${ }^{9}$.

Ibidem, s. 3.

Ibidem, s. 8.

Ibidem.

$9 \quad$ Ibidem; należy w tym miejscu wskazać, iż obowiązki przewidziane w rozporządzeniu podzielono zasadniczo na dwie grupy, w zależności od tego czy obowiązują one od dnia wejścia w życie rozporządzenia REMIT tj. od 28.12.2011 r., czy też uzależnione zostały od przyjęcia przez Komisję aktu wykonawczego do REMIT. Wraz z wejściem w życie przedmiotowego rozporządzenia uczestnicy rynku zobowiązani są do publikacji informacji wewnętrznych (jak również do powiadamiania organu regulacyjnego i ACER o przyczynach opóźnienia w ich publikacji). Ponadto obowiązuje również zakaz wykorzystania informacji wewnętrznych oraz zakaz manipulacji na hurtowych rykach energii. Pozostałe obowiązki, tj. m.in. obowiązek rejestracji uczestników rynku uzależnione zostały od wejścia w życie aktu wykonawczego do REMIT, który to Komisja przyjęła 17.12.2014 r. Jest nim rozporządzenie Komisji nr 1348/2014 w sprawie przekazywania danych wdrażające art. 8 ust. 2 i 6 rozporządzenia Parlamentu Europejskiego i Rady (UE) nr 1227/2011 w sprawie integralności i przejrzystości hurtowego rynku energii (dalej jako: rozporządzenie 1348/2014). W niniejszym rozporządzeniu Komisja: wskazuje m.in. na kontrakty, które objęte są 


\section{Zakres podmiotowy i przedmiotowy rozporządzenia REMIT}

Przepisy rozporządzenia odnoszą się do uczestników rynku, którymi zgodnie z treścią art. 2 ust. 7 i 8 REMIT są osoby fizyczne lub prawne, w tym operatorzy systemów przesyłowych, którzy przeprowadzają transakcje obejmujące składanie zleceń, na co najmniej jednym hurtowym rynku energii ${ }^{10}$. W świetle niniejszej definicji wydaje się, iż decydującym kryterium dla oceny, czy dany podmiot jest „uczestnikiem rynku”, stanowi fakt zawierania transakcji, w tym składanie zleceń, na hurtowych rynkach energii ${ }^{11}$. Tym samym pojęcie „uczestnika rynku" ma kluczowe znaczenie dla zastosowania norm zawartych w REMIT. Uzyskanie bowiem niniejszego statusu kreuje określone obowiązki. Po pierwsze, jest to obowiązek publikowania informacji wewnętrznych. Po drugie, obowiązek przekazywania ACER danych dotyczących transakcji zawieranych na hurtowych rynkach energii (w tym składanych zleceń). Po trzecie, obowiązek rejestracji w rejestrze prowadzonym przez krajowy organ regulacyjny. Obowiązki te odnoszą się w jednakowym zakresie do podmiotów z krajów trzecich, tj. podmiotów z poza UE, jak również spoza EOG ${ }^{12}$. Innymi słowy oznacza to, iż podmioty te objęte są również zakresem REMIT pod warunkiem zawierania transakcji na hurtowych rynkach energii. Potwierdza to rozumienie art. 9 ust. 1 REMIT wskazującego, iż uczestnicy rynku nie mający siedziby lub miejsca zamieszkania w UE, zawierający transakcje podlegające zgłoszeniu ACER zgodnie z art. 8 ust. 1 REMIT, zobowiązani są do rejestracji w państwie członkowskim, w którym prowadzą działalność. Można postawić w tym miejscu pytanie, co w sytuacji, w której dany podmiot prowadzi działalność w kilku państwach członkowskich UE? Rozporządzenie nie rozstrzyga tego problemu. Niemniej jednak, wydaje się, iż w takiej sytuacji dany podmiot zobowiązany będzie do rejestracji w jednym państwie członkowskim przez siebie wybranym ${ }^{13}$. Zdaje się to potwierdzać art. 9 ust. 1 REMIT wskazujący, iż uczestnik rynku rejestruje się tylko w jednym krajowym organie regulacyjnym.

wymogiem zgłoszenia do ACER (zob. art. 3 rozporządzenia 1348/2014); przyjmuje jednolite zasady przekazywania informacji, które mają być przekazywane do ACER oraz określa termin i formę przekazywania niniejszych informacji (zob. art. 7 rozporządzenia 1348/2014).

10 Zgodnie z art. 2 ust. 6 REMIT „hurtowy rynek energii oznacza każdy rynek w obrębie Unii Europejskiej, na którym prowadzony jest obrót produktami energetycznymi sprzedawanymi w obrocie hurtowym".

11 ACER, Guidance on the application of REMIT, 3rd Edition, 29.10.2013 r., s. 17, http://www. acer-remit.eu/portal/public-documentation (18.4.2015 r.).

12 Ibidem, s. 18.

13 Ibidem, s. 21; należy w tym miejscu zauważyć, iż w sytuacji, w której dany uczestnik rynku ma siedzibę w więcej niż jednym państwie członkowskim dopuszczalna będzie rejestracja tego podmiotu w państwie członkowskim, w którym znajduje się jego siedziba główna, ACER, op.cit., s. 21. 
W Polsce definicja „uczestnika rynku” odnosi się do większości przedsiębiorstw energetycznych, które uzyskały koncesje na wytwarzanie, przesył, dystrybucję lub obrót energią elektryczna (albo paliwami gazowymi) ${ }^{\mathbf{1 4}}$.

Rozporządzenie REMIT ma zastosowanie do obrotu produktami energetycznymi sprzedawanymi w obrocie hurtowym, przez które zgodnie z art. 2 ust 4, należy rozumieć następujące umowy i instrumenty pochodne bez względu na miejsce i sposób prowadzonego nimi obrotu:

a) kontrakty na dostawę energii elektrycznej lub gazu ziemnego w przypadku gdy dostawa ma miejsce w Unii;

b) instrumenty pochodne dotyczące energii elektrycznej lub gazu ziemnego wytwarzanych, sprzedawanych lub dostarczanych w Unii;

c) kontrakty dotyczące przesyłu energii elektrycznej lub gazu ziemnego w Unii;

d) instrumenty pochodne dotyczące przesyłu energii elektrycznej lub gazu ziemnego w Unii.

Wobec powyższego zakres przedmiotowy REMIT obejmuje zawierane na terenie UE, w obrocie hurtowym umowy sprzedaży (energii elektrycznej albo gazu) i umowy na usługi przesyłu oraz związane z nimi instrumenty pochodne. Należy przy tym zauważyć, iż zasadniczo kontrakty na dostawę i dystrybucję energii elektrycznej lub gazu ziemnego na potrzeby klientów końcowych nie stanowią produktów energetycznych sprzedawanych w obrocie hurtowym ${ }^{15}$. Od niniejszej zasady REMIT wprowadza wyjątek, zgodnie z którym kontrakty dotyczące sprzedaży i dystrybucji energii elektrycznej i gazu ziemnego do odbiorców o zdolności konsumpcji przekraczającej 600 GWh rocznie są traktowane jako produkty energetyczne sprzedawane w obrocie hurtowym.

Zgodnie z art. 2 ust. 5 REMIT „zdolność konsumpcji” oznacza zużycie przez klienta końcowego energii elektrycznej albo gazu ziemnego przy wykorzystaniu przez niego swojej pełnej zdolności produkcyjnej. Obejmuje ono całe zużycie przez tego klienta jako pojedynczego podmiotu gospodarczego, w zakresie, w jakim zużycie ma miejsce na rynkach, na których ceny hurtowe są ze sobą wzajemnie powiązane. Jak widać ustawodawca europejski posłużył się w tym wypadku spójnikiem alternatywy rozłącznej „albo” co pozwala stwierdzić, iż odbiorcy końcowi powinni obliczać swoje zdolności zużycia energii elektrycznej i gazu ziemnego niezależnie od siebie. Innym słowy wartości te nie kumulują się przy ocenie, czy próg 600 GWh jest lub może zostać przekroczony. W dalszej części przedmiotowej definicji wskazane zostało, iż na użytek niniejszej definicji nie jest uwzględniana zdolność konsumpcji w pojedynczych zakładach o zdolności konsumpcji mniejszej niż 600 GWh rocznie, kontrolowanych przez jeden podmiot gospodarczy, w zakresie, w jakim zakłady te nie wywierają wspólnego wpływu na ceny na hurtowym

14 T. Brzeziński, A. Mathews, Obowiq̨zki informacyjne wynikające z REMIT..., s. 23.

15 Zob. art. 2 ust. 4 rozporządzenia 1227/2011. 
rynku energii, ponieważ są zlokalizowane na różnych właściwych rynkach geograficznych. Należy w tym miejscu zgodzić się z poglądem, iż pomimo niejasnej i nieprecyzyjnej treści niniejszego przepisu, jego wykładnia a contrario pozwala uznać, iż zastosowaniem rozporządzenia REMIT objęte są również dwa lub więcej zakłady przemysłowe zużywające łącznie ponad 600 GWh energii elektrycznej lub gazu ziemnego, kontrolowane przez jeden podmiot gospodarczy i zlokalizowane na tym samym właściwym rynku geograficznym, przez co mogą one wspólnie wywierać wpływ na ceny na hurtowym rynku energii ${ }^{16}$. Innymi słowy w takim wypadku wartości te sumują się. Taka interpretacja stanowi gwarancję, iż przepis ten nie będzie obchodzony np. poprzez tworzenie kilku podmiotów, które indywidualnie zużywałyby mniej niż 600 GWh.

\section{Zakaz wykorzystywania informacji wewnętrznych}

Rozporządzenie REMIT w sposób jasny definiuje „informację wewnętrzną" wskazując na cztery jej kryteria ${ }^{17}$. Tym samym za informację wewnętrzną należy uznać informację:

a) o szczegółowym charakterze;

b) która nie została podana do publicznej wiadomości;

c) która odnosi się bezpośrednio lub pośrednio, do jednego lub więcej hurtowych produktów energetycznych;

d) która jeżeli zostałaby podana do publicznej wiadomości mogłaby znacząco wpłynąć na ceny tych produktów energetycznych sprzedawanych w obrocie hurtowym ${ }^{18}$.

Do czasu jednoczesnej i skutecznej publikacji informacji wewnętrznej w trybie określonym w REMIT, informacja ta ma charakter poufny i podlega ochronie prawnej $^{19}$.

Wydaje się, iż zasadniczym celem zakazu wykorzystywania informacji wewnętrznych jest zapobieżenie uzyskania przez dany podmiot korzyści finansowych lub przewagi konkurencyjnej ${ }^{20}$. Tym samym osoby posiadające informację

16 A. Kucińska, O. Wiśniewska, Memorandum dotyczace wskazania obowiązków przemysłowych odbiorców energii elektrycznej i innych produktów energetycznych wynikających z rozporządzenia REMIT oraz skutków ich naruszenia, Warszawa 2013, s. 4, http://www.igcp.org.pl/?q=system/files/ IEPiOE_REMIT_17.06.2013\%20opinia\%20prawna.pdf (data pobrania: 2.3.2015 r.); zob. też: ACER, op.cit., s. 14-15.

17 T. Brzeziński, A. Mathews, Obowiązki informacyjne wynikajace z REMIT..., s. 24.

18 Zob. art. 2 ust. 1 rozporządzenia 1227/2011.

19 T. Brzeziński, A. Mathews, System monitorowania hurtowych rynków energii i gazu wprowadzony rozporządzeniem REMIT - analiza obowiq̨zków uczestników rynku [w:] Zarządzanie energiq̨ i teleinformatykq, red. H. Karpońa, KAPRINT 2015, s. 4, http://wawrzynowicz.eu/category/publikacja/ (data pobrania: 22.3.2015 r.).

$20 \quad$ E. Michetti, op.cit., s. 9. 
wewnętrzną dotyczącą produktu energetycznego sprzedawanego w obrocie hurtowym nie mogą:

a) wykorzystywać takiej informacji poprzez nabywanie lub zbywanie lub próbę nabycia lub zbycia, na rachunek własny lub na rachunek osoby trzeciej, bezpośrednio lub pośrednio, produktów energetycznych sprzedawanych w obrocie hurtowym, których informacja ta dotyczy;

b) ujawniać takiej informacji jakiejkolwiek innej osobie, chyba że takie ujawnianie odbywa się w ramach standardowych czynności wykonywanych przez te osoby w ramach zatrudnienia, wykonywania swojego zawodu lub obowiązków;

c) zalecać innej osobie, w oparciu o informację wewnętrzną, nabycia lub zbycia produktów energetycznych sprzedawanych w obrocie hurtowym, do których odnosi się ta informacja, lub nakłaniania innej osoby, w oparciu o informację wewnętrzną, do nabycia lub zbycia takich produktów ${ }^{21}$.

Zakaz wykorzystywania informacji wewnętrznych ma zgodnie z treścią art. 3 ust. 2 rozporządzenia REMIT zastosowanie do następujących osób będących w posiadaniu informacji wewnętrznej dotyczącej produktu energetycznego sprzedawanego w obrocie hurtowym:

a) członków organów administrujących, zarządczych lub nadzorczych przedsiębiorstwa;

b) osób posiadających udziały w kapitale przedsiębiorstwa;

c) osób posiadających dostęp do informacji z tytułu zatrudnienia, wykonywania swojego zawodu lub obowiązków;

d) osób, które uzyskały takie informacje w wyniku działania przestępczego;

e) osób, które wiedzą lub powinny wiedzieć, że dana informacja stanowi informację wewnętrzną.

Zgodnie z zasadą zawartą w art. 4 ust. 1 rozporządzenia REMIT na uczestnikach rynku spoczywa obowiązek podawania do publicznej wiadomości posiadanych przez nich informacji wewnętrznych dotyczących przedsiębiorstwa lub instalacji, których dany uczestnik rynku lub jego jednostka dominująca, lub jednostka powiązana jest właścicielem lub które kontroluje lub w stosunku do których dany uczestnik rynku lub taka jednostka odpowiada za kwestie operacyjne w całości lub w części. Dodatkowo w rozporządzeniu podkreślono, iż obowiązek ujawniania informacji wewnętrznych obejmuje informacje dotyczące zdolności i wykorzystania instalacji służących produkcji, magazynowaniu przesyłowi energii elektrycznej lub gazu ziemnego lub zużywających energię elektryczną lub gaz ziemny bądź informacje dotyczące zdolności i wykorzystania instalacji skroplonego gazu ziemnego (LNG), w tym dotyczące planowanej i nieplanowanej niedostępności tych instalacji ${ }^{22}$. Rozporządzenie wprowadza jednakże w tym zakresie wyjątek,

21 Zob. art. 3 ust. 1 rozporządzenia 1227/2011.

22 Zob. art. 4 ust. 1 rozporządzenia 1227/2011; zasadnie podkreśla się, iż informacje dotyczące dostępności infrastruktury energetycznej wywierają istotny wpływ na decyzje uczestników rynku 
zgodnie z którym uczestnik rynku może opóźnić podanie informacji wewnętrznej do publicznej wiadomości, aby nie naruszać swych uzasadnionych interesów ${ }^{23}$. Nie mniej jednak wyjątek ten jest dopuszczalny jedynie w sytuacji, kiedy zostaną spełnione następujące warunki: po pierwsze, opóźnienie nie wprowadzi w błąd opinii publicznej. Po drugie, zapewniona zostanie poufność tej informacji. Po trzecie, nie zostaną podjęte w oparciu o tę informację decyzje dotyczące obrotu produktami energetycznymi sprzedawanymi w obrocie hurtowym. O przedmiotowym opóźnieniu uczestnik rynku zobowiązany jest niezwłocznie poinformować ACER oraz krajowego regulatora ${ }^{24}$. Ponadto w przypadku niezamierzonego ujawnienia informacji wewnętrznej przez uczestnika rynku, jego pracownika lub osobę działającą w imieniu uczestnika rynku, uczestnik rynku zapewnia całkowite i skuteczne podanie informacji do wiadomości publicznej możliwie jak najszybciej po jej niezamierzonym ujawnieniu ${ }^{25}$.

Należy zauważyć, iż rozporządzenie wprowadza również wyjątki, których zakaz ten nie obejmuje ${ }^{26}$. Przykładowo zakazem wykorzystywania informacji wewnętrznych nie będą objęte transakcje przeprowadzane w ramach wykonania zobowiązania, które stało się wymagalne, dotyczącego nabycia lub zbycia produktów energetycznych sprzedawanych w obrocie hurtowym, w przypadku gdy zobowiązanie to wynika z umowy zawartej lub zamówienia złożonego, zanim dana osoba weszła w posiadanie informacji wewnętrznej ${ }^{27}$.

Wobec powyższego wydaje się konieczne, aby osoby posiadające informacje wewnętrzne po pierwsze, nie wykorzystywały ich dla własnych korzyści, po drugie, nie ujawniały owych informacji innym podmiotom, jeżeli nie zostaną one jednocześnie udostępnione publicznie. Nadużycia w tym zakresie mogą bowiem prowadzić do zniekształcenia konkurencji na rynkach energii elektrycznej.

Informacje wewnętrzne powinny być ujawniane w sposób gwarantujący, iż staną się one dostępne dla jak największej liczby podmiotów. Preferowaną przez ACER formą publikacji informacji wewnętrznych jest zamieszczanie przedmiotowych informacji na ogólnodostępnych platformach informacyjnych (np. AGSI+ tj. Aggregated Gas Storage Inventory) ${ }^{28}$. Ponadto Agencja dopuszcza możliwość dopełnienia obowiązków publikacyjnych wskazanych w REMIT poprzez zamieszczenie

\footnotetext{
dotyczące zawarcia transakcji dotyczących produktów energetycznych w obrocie hurtownym oraz na ceny tych produktów, zob. T. Brzeziński, A. Mathews, System monitorowania hurtowych rynków energii i gazu..., s. 3.

${ }^{23}$ Zob. art. 4 ust. 2 rozporządzenia 1227/2011.

24 Ibidem.

25 Zob. art. 4 ust. 3 rozporządzenia 1227/2011.

26 Zob. art. 3 ust. 4 rozporządzenia 1227/2011.

27 Zob. art. 3 ust. 4 lit. a rozporządzenia 1227/2011.

28 T. Brzeziński, A. Mathews, System monitorowania hurtowych rynków energii i gazu..., s. 3;
} zob. też: ACER, op.cit., s. 41. 
informacji wewnętrznych na stronie internetowej zobowiązanego podmiotu, po spełnieniu następujących wymagań w tym zakresie:

- informacja wewnętrzna powinna być podana do publicznej wiadomości w sposób niedyskryminacyjny oraz nieodpłatnie;

- informacja wewnętrzna powinna zostać udostępniona przez tzw. kanał RSS umożliwiający łatwy i szybki dostęp do wiadomości publicznej;

- informacja wewnętrzna powinna być publicznie dostępna przez okres co najmniej 2 lat;

- informacja wewnętrzna powinna zostać opublikowana w języku urzędowym danego państwa członkowskiego i w języku angielskim lub tylko w języku angielskim $^{29}$.

\section{Zakaz manipulacji rynku}

Rozporządzenie definiuje manipulację rynku poprzez wskazanie w tym zakresie określonych nadużyć, które można umownie podzielić na dwie grupy. Pierwsza z nich obejmuje zawieranie jakiejkolwiek transakcji lub składanie jakiegokolwiek zlecenia dotyczących produktów energetycznych sprzedawanych w obrocie hurtowym ${ }^{30}$ :

a) które generują lub mogłyby generować fałszywe lub wprowadzające w błąd sygnały dotyczące podaży produktów energetycznych sprzedawanych w obrocie hurtowym, popytu na takie produkty lub ich ceny;

b) poprzez którą to transakcję lub zlecenie osoba lub osoby działające w porozumieniu kształtują lub próbują kształtować cenę jednego lub kilku produktów energetycznych sprzedawanych w obrocie hurtowym na sztucznym poziomie, chyba że osoba zawierająca taką transakcję lub składająca takie zlecenie wykaże, że przyczyny jej działania są zgodne z prawem, a taka transakcja lub takie zlecenie są zgodne z praktykami rynkowymi przyjętymi na danym hurtowym rynku energii; lub

c) które stosują lub próbują stosować fikcyjne mechanizmy lub wszelkie inne formy oszustwa lub podstępu, które generują lub mogłyby generować fałszywe lub wprowadzające w błąd sygnały dotyczące podaży produktów energetycznych sprzedawanych w obrocie hurtowym, popytu na takie produkty lub ich ceny ${ }^{31}$.

Do drugiej grupy zaliczyć można rozpowszechnianie poprzez media, w tym Internet, informacji, która generuje lub mogłaby generować fałszywe lub

29 Ibidem, s. 4; ACER, op.cit., s. 41-42; ponadto jak wskazano w wytycznych Agencji media społecznościowe mogą mieć jedynie charakter uzupełniający w stosunku do strony internetowej zobowiązanego podmiotu tj. nie mogą zastępować informacji publikowanych na stronie internetowej danego podmiotu, ACER, op.cit., s. 42.

30 Zob. art. 2 ust. 2 lit. a rozporządzenia 1227/2011.

31 Ibidem. 
wprowadzające w błąd sygnały dotyczące podaży produktów energetycznych sprzedawanych w obrocie hurtowym, popytu na takie produkty lub ich ceny, w tym rozpowszechnianie plotek oraz fałszywych lub wprowadzających w błąd informacji, jeżeli osoba je rozpowszechniająca wiedziała lub powinna była wiedzieć, że informacja ta jest fałszywa lub wprowadza w błąd.

\section{Monitorowanie rynku i gromadzenie danych}

W celu wykrywania i zapobiegania niewłaściwego wykorzystywania informacji wewnętrznych, jak również manipulacji rynku przez jego uczestników, REMIT nałożył na ACER i krajowe organy regulacyjne obowiązki w zakresie nadzoru i monitoringu nad działalnością handlową, której przedmiotem są produkty energetyczne sprzedawane w obrocie hurtowym.

Rozporządzenie wymaga, aby krajowe organy regulacyjne współpracowały nie tylko z ACER, ale również z sobą nawzajem. Krajowe organy regulacyjne zobowiązane są do niezwłocznego poinformowania ACER, w możliwie jak najbardziej szczegółowy sposób, w przypadku gdy mają uzasadnione podstawy, aby podejrzewać, że w danym państwie członkowskim lub w innym państwie członkowskim dochodzi lub doszło do naruszenia przepisów REMIT ${ }^{32}$. Ponadto rozporządzenie wymaga, aby osoby, które zawodowo organizują transakcje, których przedmiotem są produkty energetyczne sprzedawane w obrocie hurtowym, mające uzasadnione podejrzenie, że dana transakcja może stanowić naruszenie REMIT, powiadomiły o tym fakcie niezwłocznie krajowy organ regulacyjny ${ }^{33}$.

Jeżeli chodzi o obowiązki ACER w zakresie gromadzenia danych, rozporządzenie zobowiązuje uczestników rynku do przekazywania ACER danych na temat transakcji zawieranych na hurtowych rynkach energii ${ }^{34}$. Zgłaszane informacje powinny zawierać precyzyjnie określnie produkty energetyczne nabywane i sprzedawane w obrocie hurtowym, uzgodnione ceny i ilości, daty i godziny wykonania transakcji, ich strony i beneficjentów, a także wszelkie inne istotne informacje ${ }^{35}$. Ponadto uczestnicy rynku zobowiązani zostali do przekazania ACER oraz krajowym organom regulacyjnym informacji dotyczących zdolności i wykorzystania instalacji służących do produkcji, magazynowania, przesyłu energii elektrycznej lub gazu ziemnego lub zużywających energię elektryczną lub gaz ziemny bądź informacji dotyczących zdolności i wykorzystania instalacji skroplonego gazu

32 Zob. art. 16 ust. 2 rozporządzenia 1227/2011.

33 Zob. art. 15 rozporządzenia 1227/2011.

34 Tryb zgłaszania transakcji został szczegółowo uregulowany w rozporządzeniu wykonawczym do REMIT 1348/2014, w którym określono ponadto wykaz kontraktów objętych obowiązkiem sprawozdawczym.

35 Zob. art. 8 ust. 1 rozporządzenia 1227/2011. 
ziemnego (LNG), w tym dotyczących planowanej i nieplanowanej niedostępności tych instalacji ${ }^{36}$.

Należy zauważyć, iż działalność ACER związana z realizacją REMIT jest oceniana przez Komisję. Zgodnie z art. 7 ust. 3 REMIT „Agencja przynajmniej raz do roku składa Komisji sprawozdanie ze swojej działalności prowadzonej na podstawie niniejszego rozporządzenia i podaje to sprawozdanie do publicznej wiadomości. W sprawozdaniach tych Agencja ocenia działanie i przejrzystość różnych kategorii rynków i sposobów prowadzenia obrotu oraz może wydawać Komisji zalecenia dotyczące zasad rynkowych, norm i procedur mogących poprawić integralność i funkcjonowanie rynku wewnętrznego".

\section{Rejestracja uczestników rynku}

Kolejnym obowiązkiem nakładanym przez REMIT na uczestników rynku jest ich obligatoryjna rejestracja w rejestrze (tzw. Krajowy Rejestr Uczestników Rynku ${ }^{37}$ ) prowadzonym przez krajowy organ regulacyjny ${ }^{38}$. Informacje w nim zawarte będą przekazywane ACER w celu utworzenia europejskiego rejestru uczestników rynku. Zgodnie z postanowieniami REMIT, rejestracja będzie dokonywana, w państwie, w którym przedsiębiorcy mają siedzibę lub w którym stale zamieszkują, lub jeżeli nie posiadają siedziby w Unii, lub nie zamieszkują w Unii, w państwie członkowskim, w którym prowadzą działalnośćc ${ }^{39}$. Uczestnik rynku zarejestrowany w jednym państwie członkowskim nie będzie musiał dokonywać ponownej rejestracji w innym państwie członkowskim. Rozporządzenie zakłada, iż przedmiotowy rejestr będzie zawierał informacje wystarczające do identyfikacji uczestnika rynku, który otrzyma niepowtarzalny identyfikator. Poza podstawowymi danymi dotyczącymi m.in. nazwy podmiotu, formy prawnej, adresu siedziby itp., dany przedsiębiorca zobowiązany będzie również do udostępnienia danych

$36 \quad$ Zob. art. 8 ust. 5 rozporządzenia 1227/2011.

37 Zgodnie z założeniami zawartymi w rozporządzeniu w rejestrze każdy uczestnik rynku otrzymuje niepowtarzalny identyfikator; rejestr zawiera informacje wystarczające do identyfikacji uczestnika rynku, w tym stosowne informacje dotyczace jego numeru VAT, adresu siedziby, osób odpowiedzialnych za decyzje operacyjne i handlowe oraz najwyższej jednostki kontroli lub beneficjenta działalności handlowej prowadzonej przez uczestnika rynku, zob. art. 9 ust. 2 rozporządzenia 1227/2011.

38 Zob. art. 9 ust. 1 rozporządzenia 1227/2011; zgodnie z art. 9 ust. 2 REMIT, krajowe organy regulacyjne tworzą rejestr uczestników rynku nie później niż trzy miesiące od daty przyjęcia rozporządzenia wykonawczego. W związku z powyższym krajowe rejestry uczestników rynku powinny zostać utworzone nie później niż do 17.3.2015 r. Natomiast obowiązek zgłaszania przez uczestników rynku do ACER kontraktów powstaje z dniem 7.10.2015 r. - dla kontraktów standardowych (tj. dziewięć miesięcy od dnia wejścia w życie aktów wykonawczych) oraz z dniem 7.4.2016 r. - dla pozostałych kontraktów (tj. piętnaście miesięcy od dnia wejścia w życie aktów wykonawczych), zob. art. 12 rozporządzenia 1348/2014.

39 Zob. art. 9 ust. 1 rozporządzenia 1227/2011. 
dotyczących swojej struktury własnościowej pozwalających na identyfikację „spółki matki" czy też przedsiębiorstw powiązanych ${ }^{40}$.

Procedura rejestracji będzie składała się z następujących etapów ${ }^{41}$ :

a) przedsiębiorca zobowiązany będzie do złożenia wniosku na odpowiednim formularzu rejestracyjnym do krajowego organu regulacyjnego wraz z właściwą dokumentacją;

b) krajowy organ regulacyjny dokona weryfikacji wniosku pod kątem spełnienia reguł ustalonych w regulacjach krajowych;

c) dane po przeprowadzeniu weryfikacji przekazane zostaną przez krajowy organ regulacyjny do europejskiego rejestru uczestników rynku prowadzonego przez ACER;

d) system informatyczny ACER po wprowadzeniu danych do europejskiego rejestru uczestników rynku wyda krajowemu organowi regulacyjnemu potwierdzenia zawierające wygenerowany dla danego uczestnika niepowtarzalny identyfikator;

e) krajowy organ regulacyjny po otrzymaniu identyfikatora zakończy procedurę rejestracji i przekaże uczestnikowi informację o jej wyniku;

f) dane rejestracyjne będą dostępne równocześnie w rejestrze krajowym oraz europejskim ${ }^{42}$.

\section{Sankcje za naruszenie obowiązków przewidzianych w przepisach REMIT}

Rozporządzenie REMIT zobowiązało państwa członkowskie UE do wprowadzenia $w$ ich ustawodawstwach sankcji za jego nieprzestrzeganie oraz wyposażenia krajowych organów regulacyjnych (tj. w Polsce Prezesa URE) w uprawnienia ${ }^{43} \mathrm{w}$ zakresie prowadzenia dochodzeń i egzekwowania przepisów niniejszego rozporządzenia ${ }^{44}$. Przedmiotowe sankcje zgodnie $z$ treścią art. 18 rozporządzenia powinny być skuteczne, odstraszające i proporcjonalne oraz odzwierciedlać

$40 \quad$ A. Kucińska, O. Wiśniewska, op.cit., s. 10.

41 Ibidem.

42 A. Kucińska, O. Wiśniewska, op.cit., s. 10.

43 Zgodnie $\mathrm{z}$ treścią art. 13 ust. 2 rozporządzenia REMIT uprawnienia te mają być ograniczone do celu dochodzenia i obejmować m.in. uzyskania dostępu do wszelkich odpowiednich dokumentów; żądania informacji od każdej odpowiedniej; przeprowadzania kontroli na miejscu; żądania udostępnienia istniejących rejestrów połączeń telefonicznych i przesyłu danych; żądania zaprzestania działań sprzecznych z niniejszym rozporządzeniem; wnioskowania do sądu o zamrożenie lub zajęcie majątku; żądania nałożenia przez sąd lub właściwy organ czasowego zakazu wykonywania zawodu.

44 P. Ciołkowski, R. Kluziak, Kary za nieprzestrzeganie rozporzqdzenia REMIT, http://www.cire. pl/item,75713,14,0,0,0,0,0,kary-za-nieprzestrzeganie-rozporzadzenia-remit.html (data pobrania: 2.3.2015 r.). 
charakter, czas trwania i wagę naruszeń, szkody wyrządzone klientom oraz potencjalne korzyści osiągnięte w wyniku obrotu prowadzonego w oparciu o informacje wewnętrzne i manipulację na rynku. Ponadto sankcje za naruszenie REMIT powinny być zbieżne z sankcjami przyjętymi przez państwa członkowskie w ramach wdrażania dyrektywy $\mathrm{MAD}^{45}$. Innymi słowy państwa członkowskie przy wdrażaniu niniejszych sankcji powinny czerpać z doświadczeń zebranych na rynkach finansowych.

Wobec powyższego można zauważyć, iż rozporządzenie REMIT nie przewiduje własnego systemu sankcji z tytułu nieprzestrzegania jego postanowień, zawierając jedynie wskazówki co do charakteru i stopnia dolegliwości, w oparciu o które państwa członkowskie tworzyć mają przepisy sankcjonujące ${ }^{46}$.

\section{Rozporządzenie REMIT na gruncie prawa polskiego}

Rozporządzenie REMIT weszło w życie dnia 28.12.2011 r. Zgodnie z art. 288 TFUE wiąże ono w całości i jest stosowane bezpośrednio we wszystkich państwach członkowskich, tj. nie wymaga implementacji do krajowych porządków prawnych. Niemniej jednak przepisy rozporządzenia nie są pełne, dlatego też państwa członkowskie zobowiązane zostały do uzupełnienia jego treści na poziomie przepisów prawa krajowego m.in. w zakresie uprawnień krajowych organów regulacyjnych oraz sankcji z tytułu naruszenia obowiązków wynikających z przepisów REMIT.

Projekt nowelizacji ustawy - Prawo energetyczne oraz niektórych innych ustaw z 6.3.2015 r. (wersja 2.0) ma na celu zapewnienie stosowania przepisów REMIT. Zgodnie z projektem poszerzony zostanie katalog pojęć zawarty w art. 3 ustawy Prawo energetyczne (dalej jako: u.p.e.) poprzez dodanie pkt 50-54, które będą definiować - poprzez odwołanie się do REMIT - pojęcia: „informacji wewnętrznej”, „manipulacji na rynku”, „próby manipulacji na rynku”, „produktu energetycznego sprzedawanego w obrocie hurtowym” oraz „uczestnika rynku”.

Projekt nowelizacji zapewnia również realizację REMIT poprzez wprowadzenie systemu sankcji za naruszenie obowiązków przewidzianych w przedmiotowym rozporządzeniu. Znowelizowane przepisy mają poszerzyć katalog okoliczności upoważniających prezesa URE do nałożenia kary pieniężnej, zawarty w art. 56 u.p.e., w drodze dodania nowych punktów (39 - 44) obejmujących przypadki naruszenia REMIT (np. naruszenia obowiązków w zakresie publikacji wewnętrznych czy raportowania transakcji) ${ }^{47}$. Ponadto projektowana nowelizacja zakłada dodanie nowego rozdziału 7a odnoszącego się do przepisów karnych (art. 57a - 57f

45 Zob. pkt 31 preambuły do rozporządzenia 1227/2011.

46 A. Kucińska, O. Wiśniewska, op.cit., s. 11.

47 T. Brzeziński, A. Mathews, Obowiązki informacyjne wynikające z REMIT..., s. 25. 
u.p.e.), przewidującego sankcje karne za różne rodzaje czynów zakazanych przez REMIT, w postaci kary grzywny (w wysokości do 1000 lub do 2500 stawek dziennych, w zależności od czynu), ograniczenia wolności lub pozbawiania wolności (od 3 albo od 6 miesięcy do 3, do 5 albo nawet do 8 lat, w zależności od czynu oraz funkcji osoby popełniającej czyn). Należy więc zauważyć, jak podkreślają autorzy nowelizacji, iż projektowany system sankcji karnych za nieprzestrzeganie REMIT, należy interpretować w sposób uwzgledniający system prawa karnego w Polsce, mając w szczególności na uwadze przepisy Kodeksu karnego, jak również Kodeksu postępowania karnego ${ }^{48}$. Warto $\mathrm{w}$ tym miejscu zwrócić uwagę, iż kara grzywny w oparciu o przedmiotowe przepisy sięgnąć może nawet kilku milionów złotych. Zgodnie bowiem z art. 33 § 3 k.k. stawka dzienna nie może być niższa niż 10 złotych, ani też przekraczać 2000 złotych. W praktyce oznacza to, iż w przypadku orzeczenia przez sąd najwyższej kary grzywny, tj. 2500 stawek dziennych kara ta wynieść może nawet $5 \mathrm{mln}$ złotych ${ }^{49}$. Co więcej kara grzywny nie musi być jedyną karą, bowiem zgodnie $\mathrm{z}$ art. $33 \S 2$ k.k., kara ta może być wymierzona przez sąd obok kary pozbawienia wolności jeżeli sprawca dopuścił się czynu w celu osiągnięcia korzyści majątkowej lub gdy korzyść majątkową osiągnął.

Nowelizacja ustawy Prawo energetyczne poszerza również uprawnienia i zadania prezesa URE o kompetencje niezbędne do monitorowania hurtowego rynku energii elektrycznej, wykrywania manipulacji i prób manipulacji na rynku. Zgodnie z treścią projektowanego art. 23c ustawy PE, Prezes URE będzie mógł przeprowadzić kontrolę lub prowadzić postępowanie wyjaśniające w sprawie manipulacji lub prób manipulacji na rynku hurtowym rynku energii oraz w sprawie niezgodnego z prawem wykorzystania informacji wewnętrznej. Przepisy projektu nowelizacji ustawy PE w sposób szczegółowy określają przebieg kontroli, jak również obowiązki i uprawnienia kontrolowanego (art. 23c-23l ustawy PE).

Mając na uwadze, iż naruszenia na rynku energii mogą być połączone z naruszeniami na rynkach finansowych, jak również naruszeniami prawa konkurencji, do których to monitorowania powołane są odrębne organy, w projekcie zawarte zostały podstawy prawne do współpracy na szczeblu krajowym między prezesem URE, prezesem Urzędu Ochrony Konkurencji i Konsumentów oraz przewodniczącym Komisji Nadzoru Finansowego w celu skutecznego i sprawnego nadzoru oraz egzekwowania obowiązków nałożonych na uczestników rynku przez REMIT ${ }^{50}$.

48 Zob. Uzasadnienie do Projektu nowelizacji ustawy - Prawo energetyczne oraz niektórych innych ustaw z 6.3.2015 r. (wersja 2.0), s. 17-18.

49 Ibidem, s. 18

50 T. Brzeziński, A. Mathews, Obowiązki informacyjne wynikajace z REMIT..., s. 25. 


\section{Podsumowanie}

Efektywna konkurencja na hurtowych rynkach energii wymaga istnienia silnych i stabilnych ram regulacyjnych gwarantujących przejrzystość i integralność owych rynków. Rozporządzenie REMIT stanowi pierwszą istotną próbę regulacji UE, handlu produktami energetycznymi, opartą w głównej mierze o przepisy mające zastosowanie do rynków finansowych, poprzez rozciągnięcie dotychczasowej koncepcji obrotu instrumentami finansowymi na hurtowy rynek energii. REMIT wprowadza dwa podstawowe zakazy dotyczące informacji wewnętrznych oraz manipulacji na rynku, jak również szereg obowiązków informacyjnych odnoszących się do podmiotów działających na hurtowych rynkach energii i gazu. Wydaje się, iż RAMIT tworzy spójne ramy regulacyjne, pozwalające na skuteczne monitorowanie hurtowych rynków energii na szczeblu unijnym, umożliwiające wykrywanie nadużyć i przeciwdziałanie im. Istotną rolę w tym zakresie odgrywa zarówno ACER, jak i krajowe organy regulacyjne. Zasadniczą kwestią jest zatem $\mathrm{z}$ jednej strony istnienie ścisłej współpracy pomiędzy tymi podmiotami dla zapewnienia właściwego monitorowania i przejrzystości rynków energii, z drugiej strony, przyznanie krajowym organom regulacyjnym niezbędnych uprawnień umożliwiających im skuteczne egzekwowanie niniejszego rozporządzenia.

\section{The strengthening of the regulation on wholesale electricity markets in the light of EU Regulation No. 1227/2011 (REMIT)}

REMIT Regulation has been designed to effectively detect abuses on wholesale energy markets, such as the misuse of inside information, manipulation and any attempts to manipulate the energy market. In order to strengthen the regulation in this area REMIT requires close cooperation between ACER and national regulatory authorities and introduces tools designed to prevent market abuses, which should be sanctioned. The aim of this article is to discuss the solutions adopted on the basis of REMIT, as well as present the proposed solutions in the context of the amendment to the Energy Law. 